\title{
Impact Analysis of Sand Dredging from Alluvial Tidal River
}

\author{
Md Kabirul Islam ${ }^{1}$, Numan Al Kibriya ${ }^{1, *}$, and Md. Maruf Dustegir ${ }^{2}$ \\ ${ }^{1}$ Dept. of Environmental, Water Resources and Coastal Engineering (EWCE), Military Institute of \\ Science and Technology (MIST)-Mirpur Cantonment, Dhaka-1216, Bangladesh \\ ${ }^{2}$ Institute of Water and Flood Management (IWFM), Bangladesh University of Science and \\ Technology (BUET)-Dhaka, Bangladesh
}

\begin{abstract}
The Government of Bangladesh has planned to make a large build up area (BUA) in a newly developed sedimentary point bar (locally known as 'Char') at Lebukhali along the northern bank of Payra river in the southern part of the country. From a study it was revealed that, this sedimentary bar has to be raised by 3.45 meters from MSL to keep it free from any extreme events (like tidal and storm surge effects) for 100 years return period. Accordingly, it was planned to collect the required filling material (estimated 57.6 million $\mathrm{m} 3$ of sand/soil) by dredging the same river bed. In Bangladesh dredging of river is very popular and widely undertaken to collect filling and construction material, but its adverse impact on river bed, bank and adjacent areas are hardly probed. This study aimed at analyzing the adverse impacts of dredging from Payra River bed. Four alternative sand bars have been identified as dredging area at varying distances located both upstream and downstream of the proposed site. The dredging impacts were analyzed for different boundary conditions. The study is based on physical survey (topographic and bathymetric surveys), historical data and numerical model analysis. Numerical model is applied through Delf 3D to investigate the impact on flow parameters: flood depth and velocity magnitude. Continuous field visit and observations were made through last one year to observe real impact. The analysis revealed that dredging of any of the bars have resulted changes in flow field. The distance of dredging point does not control the flow field rather the dredging volume, depth and upstream conditions determine the effect on bank erosion. As such, the dredging locations have been prioritized considering the least possible effects on river bank erosion and founded that little erosion is taking place for both upstream and downstream region. However, the long term impacts in other areas of the river need to be investigated as the time pass.
\end{abstract}

Keywords. Buildup Area, Sandbar (Char), Dredging, Flood depth, Bank line shift.

\footnotetext{
*Corresponding author: numan.kibriya@gmail.com
} 


\section{Introduction}

Bangladesh has a large network of rivers, streams and canals with a total length of the river up to $50 \mathrm{~m}$ width at least $24,000 \mathrm{~km}$ and an area of $4,600 \mathrm{~km}^{2}$ [7]. Dredging of river bed is a common phenomenon and widely undertaken in Bangladesh. It is occasionally conducted for improving channel navigability and mostly collection of sand/ gravel/soil which are used as construction and filling materials. In Bangladesh every year millions of tons of sand/soil materials are collected through dredging river bed. Hydraulic and suction type of dredging is found cheaper and easier to transport, hence widely used. At places locally developed dredger and unscientific method of dredging techniques are used. In spite of having some positive effect of dredging like increasing navigability, it has negative consequences too. The negative impact may be both short and long term, local and remote, in upstream and downstream, in river bed and bank or adjacent areas. Dredging not only causes vertical instability in the channel bed, but also causes lateral instability in the form of accelerated stream bank erosion and channel widening. The nature of any river channel is a result of three main variables: the material properties of the bed and banks, the flow hydraulics and the sediment transport within the river. All of these variables interact to produce the channel form, and therefore an alteration in any one of them will cause a knock-on effect upon the others. River bed dredging or in stream mining directly alters the channel geometry and bed elevation [1] and lateral channel instability [2], by interrupting sediment transport and making the flow sediment-starved. Unusual depression of river bed caused due to dredging, alters the equilibrium profile of the streambed, creating a locally steeper gradient at upstream as shown in figure 1 [3]. This over-steepened nick point (with its increased stream power) commonly erodes upstream in a process known as head cutting which may propagate upstream for kilometres on the main river [4,5] and up tributaries. Again, created gravel pits trap much of the incoming sediment, passing hungry water downstream, which typically erodes the channel bed and banks to regain at least part of its sediment load [6].

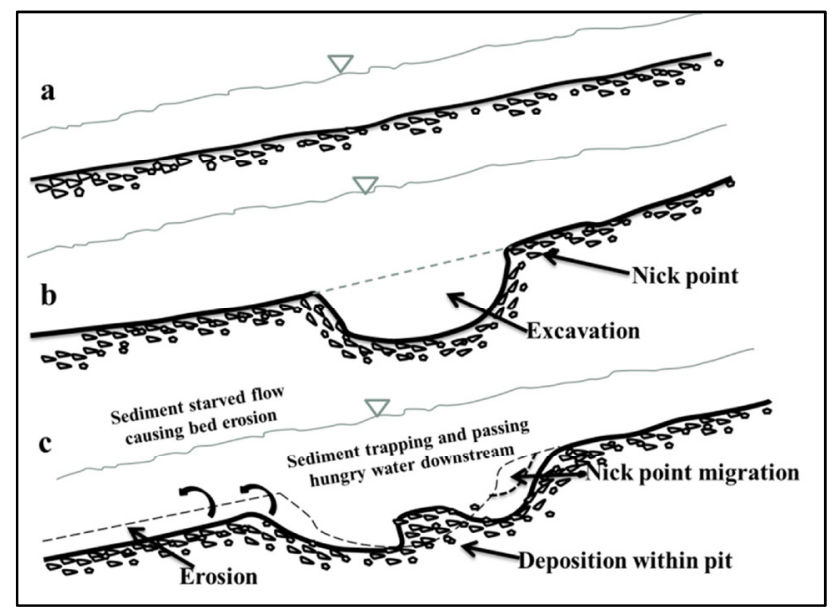

Fig. 1. Incision produced by instream gravel excavation. a) Before dredging condition. b) The excavation creates a nickpoint on its upstream c) The nickpoint migrates upstream, and hungry water erodes the bed downstream, causing incision upstream and downstream [3].

Bank erosion is a great concern for many of these rivers. Every year the country experience huge losses of land and property because of river bank erosion. In order to have effective and sustainable erosion protection measures, dozens of research works have been undertaken. Most of the research focussed on natural causes of erosion and accordingly 
protection measures were designed where impacts of river bed dredging was never studied. This might be one of the reasons of frequent failure of protection structure or initiation of bank erosion elsewhere. People generally know that near bank soil excavation may erode the bank. They are fully unaware of the negative impact of far bank or in stream excavation or dredging which whose pseudo effect may cause both short and long term erosion. Lack of research work and awareness of dredging operation lead to unopposed, unplanned and indiscriminate massive river bed dredging which may exacerbate the bank instability and in turn additional land and property losses. From this background this research aims to analyse the impacts of sand dredging from alluvial tidal river.

\section{Study Area}

The newly developed sedimentary deposited point bar $(5 \mathrm{sq} \mathrm{km})$ locally known as char along the right bank (outer) of Payra river that is $8 \mathrm{~km}$ south from Barisal town and $13 \mathrm{~km}$ north from Patuakhali town of Bangladesh is planned to convert into a developed area by Government of Bangladesh (figure 2). Payra River is a reach of tidally influenced (around $1.0 \mathrm{~m}$ tidal amplitude) meandering river about $60 \mathrm{~km}$ upstream of the mouth of the Bishkhali/Burishwar estuary. Bank erosion is a common phenomenon for both banks which occur about two kilometer length of upstream starting from the location having coordinates $22.493855^{\circ} \mathrm{N}, 90.354368^{\circ} \mathrm{E}$, where two rivers merge with Payra River. The erosion continues up to $22.476020^{\circ} \mathrm{N}, 90.349937^{\circ} \mathrm{E}$, where it bends leftwards. From this point onwards, the river banks do not face significant erosion for about four kilometres downstream. Again river bank erosion is also observed from $22.47229^{\circ} \mathrm{N}, 90.31217^{\circ} \mathrm{E}$, where the river bends rightwards which continues downstream to $22.44504^{\circ} \mathrm{N}, 90.29953^{\circ} \mathrm{E}$. The sediment deposited area experienced 2-3 m tidal variation daily which requires raising the ground level for about $3.0 \mathrm{~m}$ to $3.5 \mathrm{~m}$ to mitigate the tidal effects as well as storm surge before conducting any development work of the area.

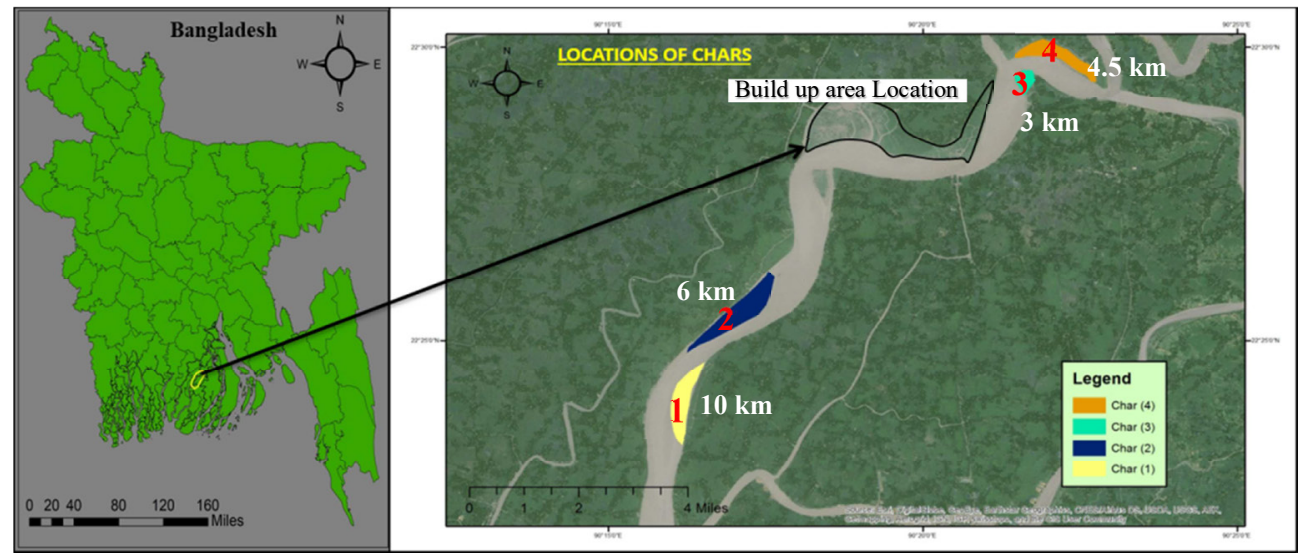

Fig. 2. Study area along with different sandbar (Char) locations.

Table 1. Location and properties of different sand bars.

\begin{tabular}{|c|c|c|c|}
\hline Bar No. & Geographic Location & $\begin{array}{c}\text { Distance from } \\
\text { Study Site }(\mathbf{k m})\end{array}$ & $\begin{array}{c}\text { Area } \\
\mathbf{( k m}^{2} \mathbf{)}\end{array}$ \\
\hline Sandbar-1 & $22^{\circ} 23^{\prime} 50.80^{\prime \prime} \mathrm{N} 90^{\circ} 16^{\prime} 8.76 " \mathrm{E}$ & 10 & 1 \\
\hline Sandbar-2 & $22^{\circ} 26^{\prime} 27.69^{\prime \prime} \mathrm{N} 90^{\circ} 17^{\prime} 41.96 " \mathrm{E}$ & 6 & 0.64 \\
\hline Sandbar-3 & $22^{\circ} 29^{\prime} 23.72^{\prime \prime} \mathrm{N} 90^{\circ} 21^{\prime} 39.01^{\prime \prime} \mathrm{E}$ & 3 & 0.24 \\
\hline Sandbar-4 & $22^{\circ} 29^{\prime} 57.44^{\prime \prime} \mathrm{N} 90^{\circ} 22^{\prime} 2.17^{\prime \prime} \mathrm{E}$ & 4.5 & 0.80 \\
\hline
\end{tabular}


As a result huge amount of refill material need to be collected to raise the ground level and the authority has decided to collect the filling materials by dredging of same river bed from four nearest sandbars. This current study will help us to find out the hydrodynamic changes of payra river channel after dredging of any of these sandbars. The possible dredging locations from different sandbars of upstream and downstream of the main channel are shown in figure 2 and their geographic location and other parameters are shown in table 1.

\section{Methodology and Analysis}

The whole study is being conducted since last two years based on primary data, field visits and measured data. ADCP was used for measuring discharge and velocity along the river reach and Echo sounder (Echotrac CVM) was used for bathymetric survey to obtain the bed profile in different time period as shown in figure 3. Delft 3D- two dimensional hydrodynamic model is applied to study the different sandbars excavation impacts on the main channel as well as the outer bank line (build up area boundary) of the study area.

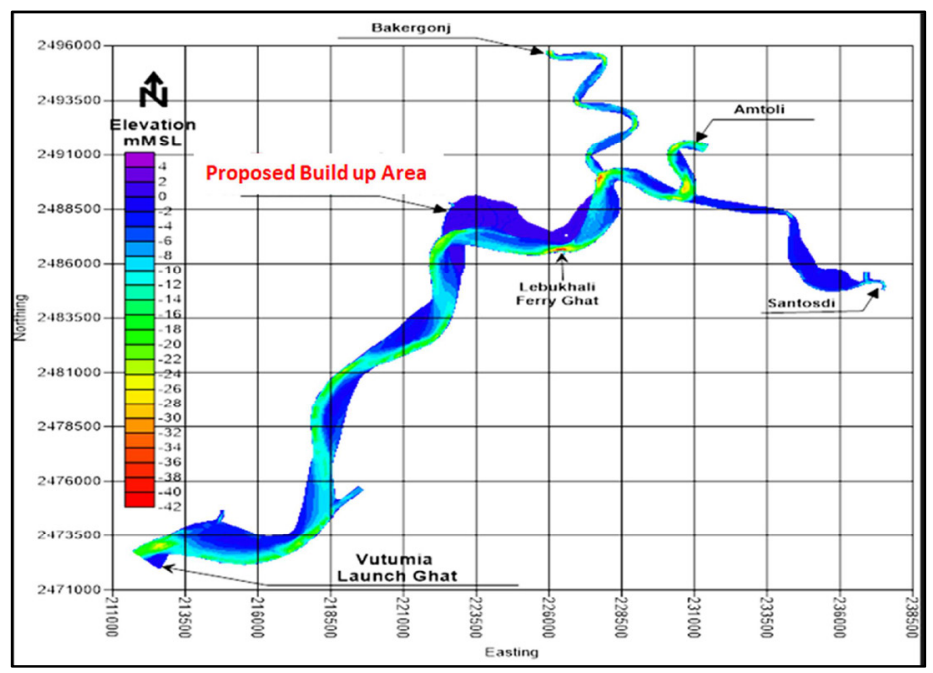

Fig. 3. Contour map of Bathymetric survey of the study area.

The baseline model covers a $14.3 \mathrm{~km}$ long aerial distance along the river that includes all the Sandbars in the region. For the hydrodynamic analysis, the maximum discharge during the 1998 flood condition and tidal range $3 \mathrm{~m}$ is applied. The model is calibrated and validated using the measured data from bathymetric and discharge measurement survey. Validated model is applied to simulate changes in flow parameters for different sandbar excavation scenarios i.e. 'before dredging' and 'after dredging'. Flow parameters are represented by flooding condition at the study area and velocity magnitude at the main channel in the vicinity of the study area. Bars excavation scenarios are shown in table 2.

Table 2. Location and properties of different sand bars.

\begin{tabular}{|c|c|}
\hline Scenarios & Dredged Sandbars \\
\hline Scenario 1 & 1 \\
\hline Scenario 2 & 1 and 2 \\
\hline Scenario 3 & 3 \\
\hline Scenario 4 & 4 \\
\hline
\end{tabular}




\section{Results and Discussion}

Simulated results of different scenarios are shown in figure 4 and 5 . The relative flood depth of the study area and estimated velocity for various sections are presented in table 3 and table-4 respectively.
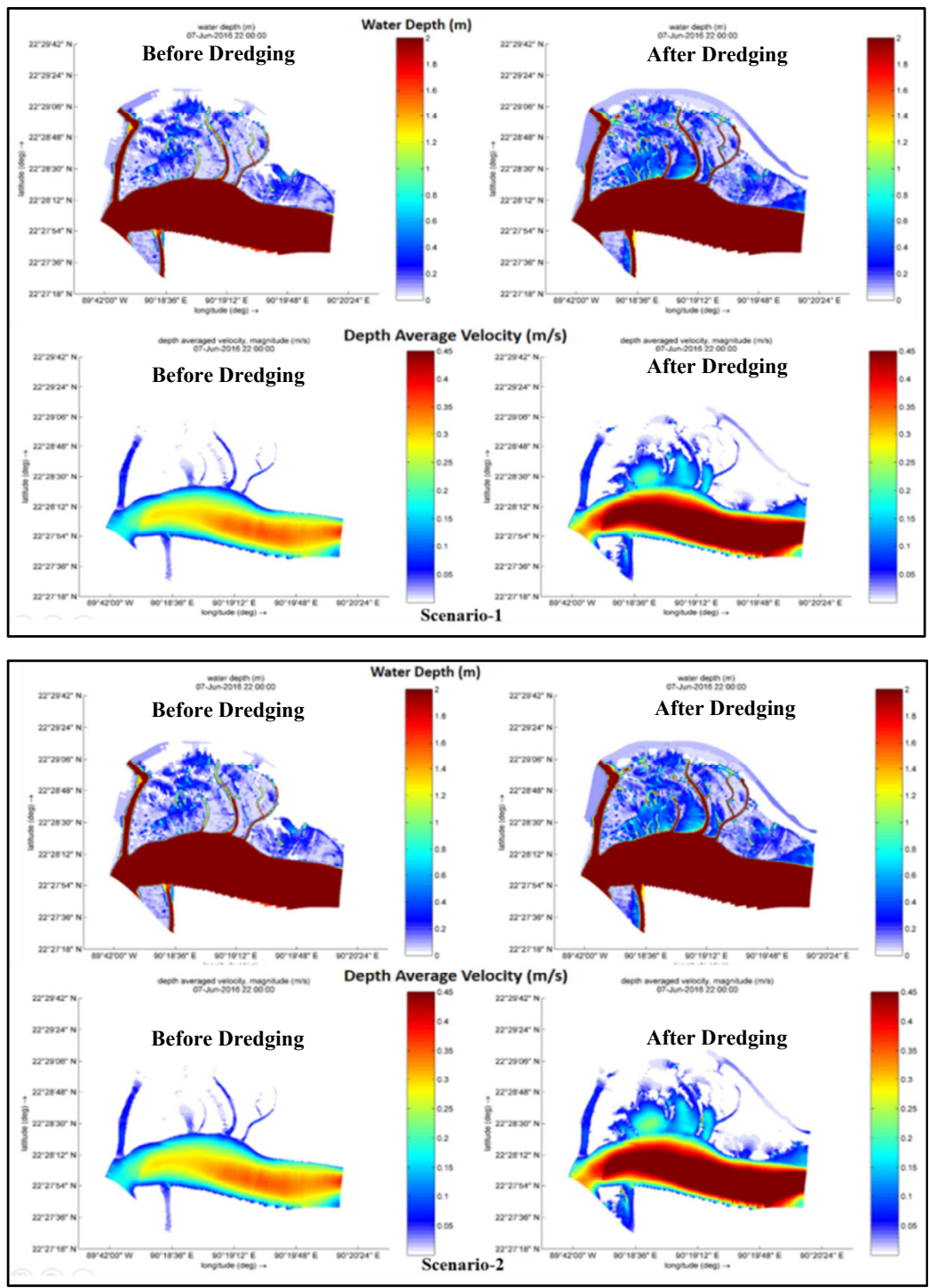

Fig. 4. Simulated flow field results from hydrodynamic analysis (Scenario $1 \& 2$ ).

From simulation it shows that for scenario-1which is dredging of sabdbar-1 will cause the minimum flood depth increase over $450 \%$. This indicates flooding will increase in the study area due to excavation of Sandbar-1. When depth average velocity in the main channel is compared, it is found that velocity is increased by almost $200 \%$ in the mid channel and more than $100 \%$ in the right bank of the main channel (build up area boundary) which indicates bank erosion will increase. Impacts on flow field due to scenario-2 show that minimum flood depth in the study area is increased to $460 \%$, where minimum right bank velocity will increase $114 \%$ and $179 \%$ for main channel. Both of these values are greater 
Table 3. Estimated flood depth for different scenarios

\begin{tabular}{|c|c|c|c|c|c|c|}
\hline \multirow{2}{*}{ Scenarios } & \multicolumn{3}{|c|}{ Flood depth (m) before dredging } & \multicolumn{3}{c|}{ Flood depth increased (\%) after Dredging } \\
\cline { 2 - 7 } & $\begin{array}{c}\text { Maximu } \\
\text { m }\end{array}$ & Minimum & Average & Maximum & Minimum & Average \\
\hline Scenario-1 & 0.33 & 0.06 & 0.18 & 58 & 458 & 116 \\
\hline Scenario-2 & 0.33 & 0.06 & 0.18 & 67 & 460 & 130 \\
\hline Scenario-3 & 0.33 & 0.06 & 0.18 & 0.09 & 0.04 & 28 \\
\hline Scenario-4 & 0.33 & 0.06 & 0.18 & 0.08 & 0.07 & 33 \\
\hline
\end{tabular}

than the scenario-which will also lead to increase bank erosion. For excavation of sandbar-3 as scenario- 3 the average flood depth in the study area will increase by almost $28 \%$ and minimum velocity is increased by almost $140 \%$ in the mid channel whereas minimum velocities at both right and left banks of the main channels are increased by $67 \%$ which is much less than for scenario $1 \& 2$. Finally for scenario-4 average flood depth in the study location will increase by almost $33 \%$ which is much less than compared to the scenarios of char-1 excavation and char-1 \& char-2 excavations, but more than scenario-3. When depth average velocity in the main channel is compared, it is found that minimum velocity is increased by almost $140 \%$ in the mid channel whereas minimum velocities at right bank of the main channel and left bank of the main channel are increased by $71 \%$ and $66 \%$ respectively. So dredging of sandbar-3 is the safest than dredging of sandbar-1 or 2 or 4 . The next safe option may be excavation of sandbar- 4 where sufficient protection measures must be undertaken before dredging of sandbar 1 and 2 .

Table 4. Estimated velocity for various sections for different scenarios

\begin{tabular}{|l|c|c|c|c|c|c|c|}
\hline \multirow{3}{*}{ Scenarios } & \multirow{2}{*}{ Location } & \multicolumn{3}{|c|}{$\begin{array}{c}\text { Velocity (m/s) before } \\
\text { excavation }\end{array}$} & \multicolumn{3}{c|}{$\begin{array}{c}\text { Velocity (m/s) increased (\%) } \\
\text { After Excavation }\end{array}$} \\
\cline { 3 - 8 } & & Max & Min & Avg & Max & Min & Avg \\
\hline \multirow{3}{*}{ Scenario-1 } & Left Bank & 0.26 & 0.12 & 0.20 & 70 & 86 & 66 \\
\cline { 2 - 8 } & Right Bank & 0.37 & 0.10 & 0.20 & 75 & 108 & 72 \\
\cline { 2 - 8 } & Mid Channel & 0.34 & 0.14 & 0.24 & 71 & 209 & 111 \\
\hline \multirow{3}{*}{ Scenario-2 } & Left Bank & 0.26 & 0.12 & 0.20 & 73 & 89 & 69 \\
\cline { 2 - 8 } & Right Bank & 0.37 & 0.10 & 0.20 & 79 & 114 & 76 \\
\cline { 2 - 8 } & Mid Channel & 0.34 & 0.14 & 0.24 & 74 & 179 & 104 \\
\hline \multirow{3}{*}{ Scenario-3 } & Left Bank & 0.26 & 0.12 & 0.20 & 59 & 67 & 56 \\
\cline { 2 - 8 } & Right Bank & 0.37 & 0.10 & 0.20 & 60 & 67 & 55 \\
\cline { 2 - 8 } & Mid Channel & 0.34 & 0.14 & 0.24 & 60 & 140 & 83 \\
\hline & Left Bank & 0.26 & 0.12 & 0.20 & 58 & 66 & 55 \\
\cline { 2 - 8 } & Right Bank & 0.37 & 0.10 & 0.20 & 59 & 71 & 54 \\
\cline { 2 - 8 } & Mid Channel & 0.34 & 0.14 & 0.24 & 59 & 138 & 82 \\
\hline
\end{tabular}

In order to fulfil the requirement of filling material which was estimated to be about 4.5 million cubic meter, the authority decided to dredge submerged sandbar- 2 which is about 4 $\mathrm{km}$ downstream from build-up area. Dredging took few months starting from January 2017. Suction type of dredging technology was used. Dredging operation was carried out by the unskilled people and dredging was not done to the uniform depth all over the sand bar. Whole reach was observed throughout the year and some effects were observed. Erosion was observed along the right bank at $2 \mathrm{~km}$ upstream from dredging point as shown in Figure 6 (a). There was no erosion in this area in 

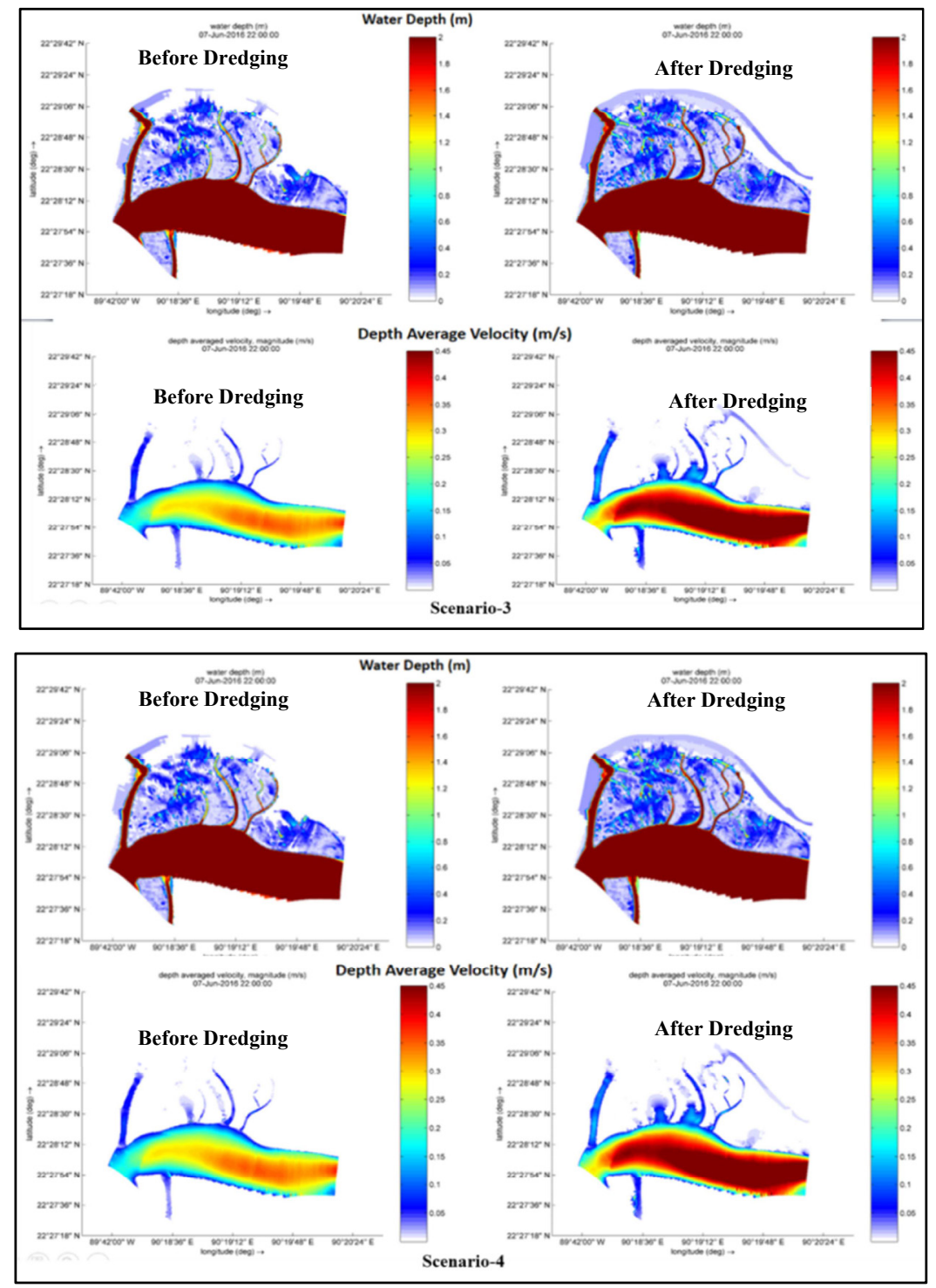

Fig. 5. Simulated flow field results from hydrodynamic analysis (Scenario $3 \& 4$ ).

the previous year during field visit. From Bathymetric survey the thalweg is found shifted towards this bank. This effect was observed nearly after 2 month of the commencement of dredging activity. After about 4 months (from the end of dredging) significant erosion was observed along the filling area which is about $4 \mathrm{~km}$ upstream from the dredging point Figure 6 (f). The erosion was not continuous and uniform. Decreasing rate of erosion was observed with the increasing distance from the dredging location. Increased flow velocity was observed along this reach during ebb tide. Erosion rate and flow velocity both were more than previous years which was confirmed from previously conducted feasibility study $[8]$. 


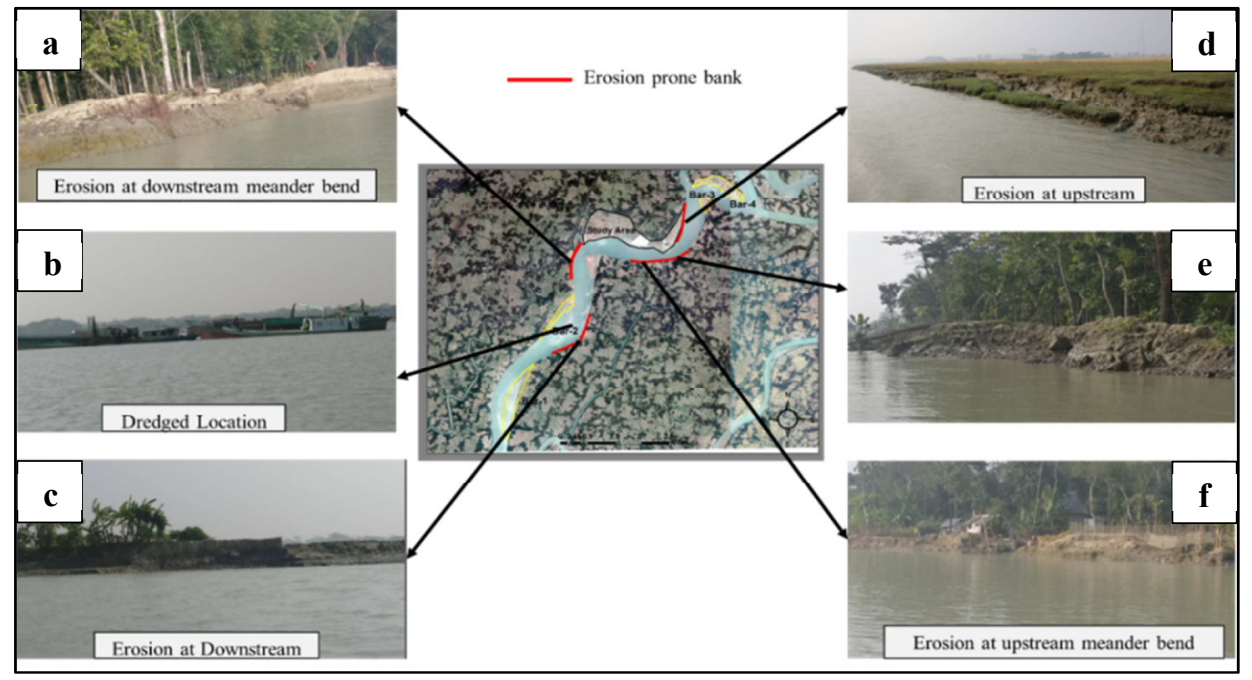

Fig. 6. Erosion Scenario within the study area after dredging (Photograph by author, July 2017)

\section{Conclusion}

Dredging of sandbar-2 creates direct influence on bank erosion as proper method and techniques were not used and also the hydrodynamic changes were not taken into consideration. Though the bank erosion decreases as the distance of dredging location increases, it will have control to change the geological and also morphological behaviour of the river that may disturb the stability of land. So controlled dredging with regular monitoring may be conducted for collecting refill materials and also for navigability where studies related to changes of geological and also morphological behaviour must be done.

\section{References}

1. M. Sandecki, Aggregate mining in river systems, California Geology, 42(4), 88-94 (1989).

2. G. M. Kondolf, Geomorphic and environmental effects of instream gravel mining, Landscape and Urban Planning 28:225-243 (1994).

3. G. M. Kondolf, PROFILE: Hungry water: effects of dams and gravel mining on river channels, Environmental management. 21. 533-51(1997).

4. K. M. Scott, Scour and fill in Tujunga Wash - a fanhead valley in urban southern California-1969. US Geological Survey Professional Paper 732-B (1973).

5. M. A. Stevens, B. Urbonas, L. S. Tucker, Public-private cooperation protects river. APWA Reporter September:25-27 (1990).

6. Sand Mining Facts, Impacts of Sand Mining, The Ojos Negros research Group, http://ponce.sdsu.edu/three issues sandminingfacts01.html

7. Md. M. RAHMAN, M. A. Rahman, Md. M. Rahman, Effectiveness of River Training Structures in Bangladesh, ICSE6 Paris - August 27-31 (2012).

8. M. K. Islam, M. M. Dustegir, M. M. rahman, M. Rahman, Changes in Planform and Meander bends of Rivers in Southern Estuarine Region of Bangladesh and Its Implications on Development Project, Proceeding of civil and water resources engineering conference, 3-4 November 2017, ISBN : 978-1-925488-52-4 (2017) 